\title{
Training of Trainers (ToT) bagi Para Instruktur Bahasa Korea di LPK (Lembaga Pelatihan Kerja) Bahasa Korea di Indonesia
}

\author{
Suray Agung Nugroho \\ Departemen Bahasa dan Sastra, Fakultas Ilmu Budaya, Universitas Gadjah Mada \\ Posel: suray@ugm.ac.id
}

Tim Pengabdian kepada Masyarakat

Febriani Elfridda Trihtarani, Hwang Who Young, Iva Hanani, Suhandano, Suray Agung Nugroho, Tri Mastoyo J.K

\begin{abstract}
The community service (Pengabdian kepada Masyarakat/PkM) held in 2019 is a continuation of PkM which was carried out in 2018 on how LPK (Lembaga Pelatihan Kerja) instructors and students interpret the EPS TOPIK (Employment Permit System - Test of Proficiency in Korean Language). Based on the assessment of the ability and weaknesses of prospective PMI (Pekerja Migran Indonesia=Indonesian Migrant Workers) in understanding Korean, the Korean Language and Culture Program conducted the second PkM which was specifically intended for instructors at LPK through Training of Trainers (ToT). The ToT participants were 30 instructors, members of PELBAKORI (Association of Korean Language LPK in Indonesia). The material provided in this ToT were: (a) Important steps to mastering Korean vocabulary and grammar and (b) Points to ponder in understanding Korean culture.
\end{abstract}

Keywords: Korean Languange Instructors, PELBAKORI, Indonesian Migrant Workers, EPS TOPIK

\begin{abstract}
Abstrak
PkM yang dilakukan pada tahun 2019 ini adalah kelanjutan dari PkM yang dilaksanakan pada tahun 2018 tentang bagaimana instruktur LPK (Lembaga Pelatihan Kerja) dan peserta didik memaknai EPS TOPIK (Employment Permit System-Test of Proficiency in Korean Language). Berdasarkan asesmen kemampuan dan kelemahan para calon PMI (Pekerja Migran Indonesia) dalam memahami bahasa Korea yang telah diperoleh dalam kegiatan PkM tahap pertama, Prodi Bahasa dan Kebudayaan Korea merancang PkM kedua yang khusus ditujukan untuk para instruktur di LPK, yaitu Training of Trainers (ToT) bagi pengajar bahasa Korea di LPKLPK Bahasa Korea. Peserta ToT berjumlah 30 instruktur di LPK penyelenggara kursus bahasa Korea yang tergabung dalam PELBAKORI (Perhimpunan LPK Bahasa Korea se-Indonesia). Materi yang diberikan dalam ToT ini adalah (a) langkah-langkah penting dalam menguasai tata bahasa dan kosakata bahasa Korea dan (b) pengetahuan sekitar budaya Korea.
\end{abstract}

Kata Kunci: Instruktur bahasa Korea, PELBAKORI, Pekerja Migran Indonesia, EPS TOPIK 


\section{Latar Belakang}

Dalam skema kerja sama $G$ to $G$ (Government to Government) antara pemerintah Indonesia dan Korea Selatan (selanjutnya disebut Korea), setiap tahunnya, Indonesia memiliki kesempatan untuk mengirimkan 5.000-an PMI (Pekerja Migran Indonesia) untuk bekerja di berbagai SME (Small \& Medium Enterprises) di Korea. Untuk memperebutkan jatah tersebut, berdasarkan data BNP2TKI (Badan Nasional Penempatan dan Perlindungan Tenaga Kerja Indonesia), terkuak bahwa pada tahun 2017, misalnya, jumlah peminat atau pendaftar pekerja di Korea mencapai 23.900-an orang untuk memperebutkan sekitar lima ribu kuota tersebut.

Di tengah fakta itu, perlu diketahui dua hal penting. Pertama, untuk layak menjadi calon PMI, seseorang harus lulus ujian EPS TOPIK (Employment Permit System Test of Proficiency in Korean Language) yang sudah menjadi syarat multak untuk maju ke tahap selanjutnya. Kedua, untuk lulus ujian tersebut, seseorang perlu belajar bahasa Korea terlebih dahulu, baik secara autodidak atau belajar sendiri maupun mengikuti kursus atau pendidikan bahasa Korea di lembaga-lembaga pelatihan kerja (LPK) bahasa Korea yang banyak tersebar di berbagai daerah di Indonesia.

Terkait dengan pelatihan bahasa Korea di LPK-LPK Bahasa Korea, ada dua poin penting yang perlu diketahui. Pertama, LPK telah menjadi salah satu penolong calon PMI yang bermimpi untuk bekerja di Korea. Di lembaga-lembaga seperti ini, pada umumnya, mereka mendapatkan paparan bahasa Korea untuk pertama kalinya yang diharapkan dapat membantu mereka mendapatkan skor tertentu untuk lolos tes EPS TOPIK. Hal itu ditopang pula dengan fakta bahwa LPK-LPK tersebut memberikan muatan latihan-latihan soal EPS TOPIK yang memungkinkan calon PMI untuk terbiasa dengan model tes. Kedua, LPK-LPK Bahasa Korea di Indonesia rata-rata mengandalkan tenaga pengajar atau instruktur bahasa Korea yang sebagian besar dari mereka adalah mantan PMI yang telah pulang dari Korea. Terkait dengan poin ini, dapat dikatakan bahwa walaupun mereka mengetahui dan dapat berbahasa Korea, mereka tidak memiliki latar belakang pendidikan dan pengajaran bahasa Korea secara formal.

Tanpa mengesampingkan peran vital mereka dalam meloloskan anak didiknya sehingga banyak dari anak didiknya berhasil sampai ke Korea, ada satu hal penting yang menarik perhatian Prodi Bahasa dan Kebudayaan Korea FIB UGM (selanjutnya disebut Prodi Korea). Tak lain dan tak bukan adalah masih perlunya para instruktur bahasa Korea di LPK-LPK itu untuk mendapatkan pelatihan khusus terkait dengan metode dan konten pengajaran bahasa Korea yang seharusnya dapat diajarkan di LPKLPK mereka. Hal ini mengingat fakta bahwa banyak LPK yang masih mementingkan tujuan bagaimana agar peserta kursusnya dapat lolos tes EPS TOPIK tanpa memberikan perhatian khusus pada pentingnya pengetahuan tentang bagaimana menggunakan bahasa Korea tersebut dalam kehidupan sehari-hari saat anak didik itu benar-benar bekerja di Korea.

Memahami masalah-masalah tersebut, Prodi Korea telah mengadakan serangkaian program Pengabdian kepada Masyarakat $(\mathrm{PkM})$ secara berkelanjutan untuk ikut mengatasi hal itu. PkM yang kami lakukan pada Mei 2019 ini adalah lanjutan dari PkM Oktober 2018 yang bergelut dengan isu bagaimana instruktur LPK dan peserta didik memaknai EPS TOPIK (Nugroho, 2019). Hasil utama dan penting dari PkM 
pertama tersebut adalah terpetakannya kondisi kemampuan bahasa Korea calon PMI. Kemampuan dan kelemahan para calon PMI dalam memahami bahasa Korea menjadi pembuka akses bagi Prodi Korea untuk merancang PkM kedua yang khusus ditujukan untuk para instruktur di LPK, yaitu Training of Trainers (ToT) bagi pengajar bahasa Korea di LPK-LPK Bahasa Korea.

\section{Sekilas Pandang Hasil Training of Trainers (ToT)}

Seperti yang telah disinggung dalam latar belakang, kegiatan ToT bagi para instruktur bahasa Korea adalah kelanjutan dari program PkM tahap 1 (Oktober 2018). Untuk itulah, ada dua tujuan utama ToT ini, yaitu (1) meningkatkan kemampuan bahasa Korea para instruktur di LPK Bahasa Korea dan (2) meningkatkan kemampuan mengajarkan bahasa Korea para instruktur di LPK Bahasa Korea. Dapat dikatakan bahwa ToT yang telah dilangsungkan pada 4-5 Mei 2019 ini sungguh di luar dugaan. Berlangsung selama dua hari di Aula Balai Pelayanan Penempatan dan Perlindungan Tenaga Kerja Indonesia (BP3TKI) Yogyakarta di Jalan Sambisari No. 311 Purwomartani, Yogyakarta, sejumlah 30 orang peserta dengan bangga menyatakan bahwa mereka memang memerlukan kegiatan seperti itu. Mereka pulang dari acara ToT ini dengan lebih percaya diri dan tidak sabar untuk segera mentransfer ilmu mereka kepada anak didik di LPK masing-masing.

Sekali lagi, dapat dikatakan bahwa ToT ini berhasil menggaet sebanyak 30 instruktur di LPK penyelenggara kursus bahasa Korea yang tergabung dalam PELBAKORI (Perhimpunan LPK Bahasa Korea se-Indonesia). Peserta terbanyak berasal dari berbagai LPK di Jawa Tengah, seperti dari Semarang, Purwokerto, Cilacap, Brebes, Temanggung, Jepara, Purwodadi, Banyumas, Sragen, Magelang, Grobogan, Salatiga, dan Karanganyar. Dari Jawa Timur berasal dari dua kota, yaitu Jember dan Tulungagung. Sementara itu, peserta dari Jawa Barat hanya satu, yakni berasal dari Kota Cirebon. Bahkan, ada pula dua peserta yang datang dari luar Jawa seperti Lombok dan Lampung. Terakhir, tentu saja peserta dari Provinsi Yogyakarta tak ketinggalan ikut serta dalam kegiatan ini.

Perlu diketahui bahwa 30 peserta ini dipilih dari sekitar 60 calon peserta ToT yang telah mendaftarkan diri melalui PELBAKORI. Untuk itulah, Prodi Korea pun berencana untuk terus mengadakan kegiatan ToT ini demi merangkul sebanyak-banyaknya para instruktur bahasa Korea yang sadar dengan pentingnya penyegaran kembali kemampuan bahasa Korea mereka.

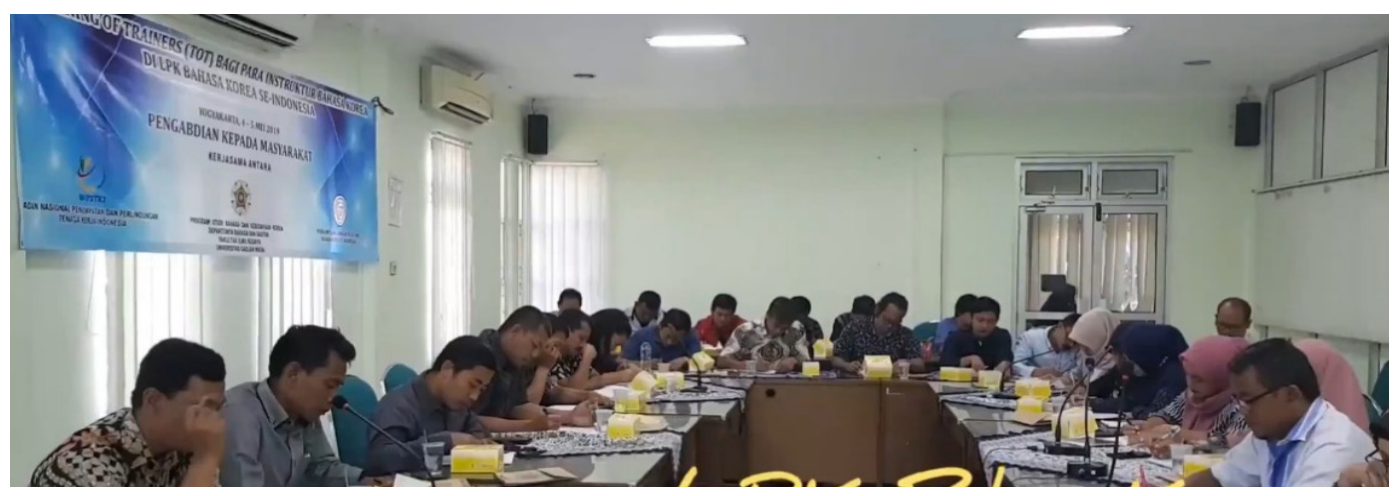

Gambar 1. Suasana ToT bagi Instruktur Bahasa Korea di LPK Bahasa Korea. 


\section{Keterlibatan Masyarakat Sasaran}

Demi melangsungkan rencana kesinambungan ToT ini, Prodi Korea menyadari bahwa keberhasilan ToT tak mungkin terwujud tanpa kerja sama dengan pihak dan institusi lainnya. Ada dua institusi yang perlu dijelaskan di sini, yaitu PELBAKORI dan BP3TKI Yogyakarta.

Dengan melibatkan instruktur bahasa Korea yang tersebar di seluruh Indonesia melalui wadah PELBAKORI, Prodi Korea sebagai pelaksana PkM merangkul subjek penting dalam lingkaran pengiriman calon PMI ke Korea. Para instruktur bahasa Korea di LPK adalah anggota masyarakat yang mempunyai peran penting dalam melancarkan proses pengiriman calon PMI ke Korea. Mereka secara tidak langsung juga membantu anggota masyarakat lain yang ingin mengubah taraf kesejahteraan keluarganya dengan menjadi tenaga kerja migran di luar negeri.

Dapat dikatakan bahwa dalam kegiatan ini, PELBAKORI menjadi mitra penting dalam kegiatan $\mathrm{PkM}$. Mereka memegang peran penunjang dalam kegiatan PkM karena merekalah yang aktif mewadahi para LPK yang mengajarkan bahasa Korea. Dengan secara langsung melibatkan PELBAKORI melalui PkM ini, Prodi Korea dengan kapasitas dan kemampuan SDM yang dimiliki dapat dengan mudah merangkul semua instruktur bahasa Korea di LPK se-Indonesia. Selain itu, PELBAKORI juga aktif memberikan berbagai macam informasi terkait dengan jumlah instruktur dan instruktur LPK mana saja yang perlu dipilih menjadi peserta dalam $\mathrm{PkM}$ ini. Peran organisasi ini sangat penting dalam melancarkan $\mathrm{PkM}$ dan hal ini menunjukkan kepercayaan mereka terhadap Prodi Korea selaku pelaksana ToT melalui kegiatan PkM.

Semenjak Prodi Korea memaparkan hasil PkM tahap 1 tahun 2018 di depan para anggota PELBAKORI dan para penentu kebijakan di BP3TKI (Badan Pelayananan Penempatan Perlindungan Tenaga Kerja Indonesia) Yogyakarta, kedua pihak itulah yang dengan tangan terbuka menyambut rencana PkM seperti ToT ini. Untuk itulah, secara singkat dapat disimpulkan bahwa terlibatnya para instruktur bahasa Korea di LPK, PELBAKORI, dan BP3TKI menunjukkan dua hal, yaitu (a) peran aktif lapisan masyarakat lain, dalam hal ini lembaga nonpemerintah (PELBAKORI) dan badan pemerintah (BP3TKI) dalam kegiatan PkM ini dan (b) peran aktif universitas melalui Prodi Korea FIB UGM untuk terjun mencari solusi terkait problematika seputar pengiriman PMI ke Korea, dalam hal ini perlunya peningkatan kemampuan bahasa Korea para instruktur bahasa Korea di LPK-LPK Bahasa Korea se-Indonesia.

\section{Pelaksanaan Kegiatan ToT}

Acara dimulai pada Sabtu, 4 Mei 2019 dan dibuka oleh Kepala BP3TKI Yogyakarta, yaitu Bapak Suparjo, S.H., dan Ketua Prodi Bahasa dan Kebudayaan Korea, yaitu Dr. Tri Mastoyo, M.Hum., yang keduanya saling memberikan apresiasi atas kerja sama yang dijalin. Setelah itu, kegiatan dimulai dengan materi pertama dari Dr. Suray Agung Nugroho yang membicarakan tata cara ToT, pentingnya para peserta memahami tujuan kegiatan, dan pentingnya perubahan sikap para instruktur bahasa Korea dalam menyikapi dirinya sebagai seorang pendidik. Dr. Suray menekankan agar para instruktur bahasa Korea tidak berhenti belajar bahasa Korea mengingat perkembangan dan penggunaan 
bahasa Korea yang meluas dengan cepat. Selain itu, pemateri juga mengingatkan bahwa peran instruktur tidak hanya terletak untuk meluluskan atau mengajarkan konten terkait EPS TOPIK, tetapi mereka juga harus sadar tentang pentingnya materi budaya yang termuat dalam buku panduan bahasa Korea yang mereka gunakan. Mereka harus mencari dan menemukan cara yang cocok—sesuai LPK mereka_-agar materi-materi itu dapat membantu para calon PMI untuk mampu berkomunikasi dalam bahasa Korea dan memahami betul budaya Korea.

Tabel 1. Jadwal kegiatan ToT

\begin{tabular}{|c|l|l|}
\hline \multicolumn{1}{|c|}{ Tanggal } & \multicolumn{1}{|c|}{ Waktu } & \multicolumn{1}{c|}{ Kegiatan } \\
\hline Sabtu, 4 Mei 2019 & $09.00-09.30$ & Persiapan acara di BP3TKI dan Pembukaan \\
\cline { 2 - 3 } & $09.30-12.00$ & $\begin{array}{l}\text { Sesi I ToT } \\
\text { Suray Agung Nugroho, M.A., Ph.D. }\end{array}$ \\
\cline { 2 - 4 } & $12.00-13.00$ & Istirahat, Makan Siang, Salat \\
\cline { 2 - 4 } & $13.00-15.30$ & $\begin{array}{l}\text { Sesi II ToT } \\
\text { Hwang Who Young, M.A. }\end{array}$ \\
\cline { 2 - 4 } & 15.30 & Penutupan Hari 1 \\
\hline Minggu, 5 Mei 2019 & $09.00-10.00$ & $\begin{array}{l}\text { Sesi III ToT } \\
\text { Iva Hanani, S.S., M.A. } \\
\text { Alfiana Rosyadi, S.S., M.A. }\end{array}$ \\
\cline { 2 - 4 } & $11.00-12.30$ & $\begin{array}{l}\text { Praktek I Para Peserta ToT } \\
\text { Febriani Elfida Trihtarani, S.S., M.A. } \\
\text { Materi dari BP3TKI tentang } \\
\text { Keselamatan dan Hak Pekerja }\end{array}$ \\
\cline { 2 - 3 } & $12.30-13.00$ & Makan Siang dan Penutupan \\
\hline
\end{tabular}

Pemateri selanjutnya, yaitu Febriani, Hwang Who Young, Iva Hanani, dan Alfiana sonsaengnim membagi penyampaian materi berdasarkan modul-modul yang dipakai oleh para pengajar bahasa Korea di LPK-LPK. Namun, mengingat banyaknya jumlah materi di modul yang tidak mungkin untuk dipaparkan secara detail dalam waktu yang singkat, keempat pemateri memutuskan untuk membagi tugas dengan memilih bab-bab yang dianggap penting dan wajib diketahui oleh para instruktur. Berikut ini adalah konten yang disampaikan oleh tiap pemateri.

a) Materi kosakata, kalimat langsung tak langsung, dan budaya yang terkait dengannya, yang dibawakan oleh Febriani sonsaengnim.

Inti pemaparan yang disampaikannya adalah pentingnya setiap pengajar memahami cara mengemas kosakata-kosakata yang ada pada tiap bab di modul sebagai materi budaya. Dengan kata lain, kosakata bukan sekadar dihafalkan, melainkan juga harus digunakan sebagai materi pengajaran agar peserta kursus bahasa Korea dapat membayangkan pentingnya pengetahuan kosakata-kosakata yang mereka pelajari.

b) Materi kosakata dan tata bahasa di lingkungan kerja yang disampaikan oleh Alfiana sonsaengnim.

Alfiana sonsaengnim menekankan kepada para pengajar untuk memahami kosakata pada tiap bab sebelum diajarkan dan memastikan agar para peserta paham kosakata 


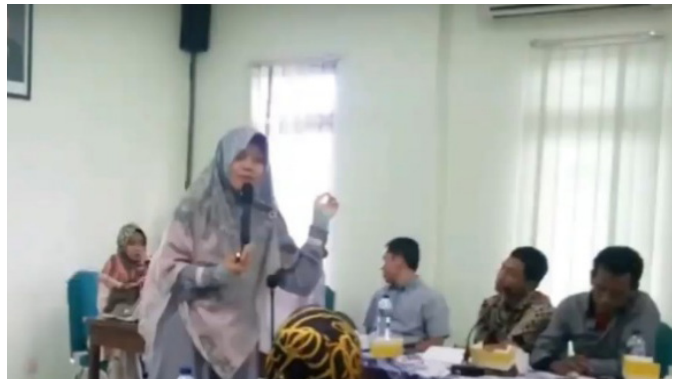

Gambar 2. Febriana Sonsaengnim Memberikan Materinya.

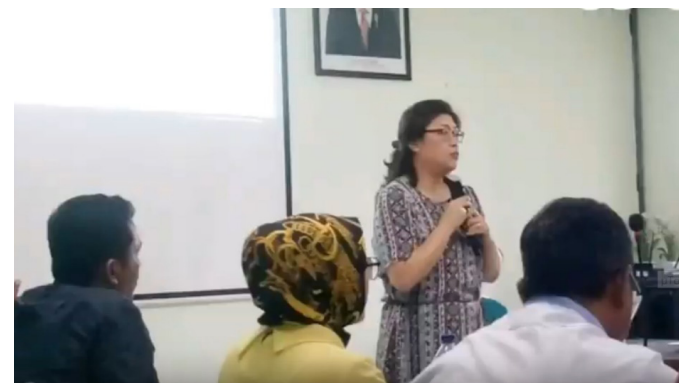

Gambar 3. Hwang Who Young Sonsaengnim Memberikan Materi Pelatihan.

dan tata bahasa yang terkait dengannya. Terlebih lagi, para pengajar harus menyadari pentingnya intonasi dalam mengucapkan suatu kosakata atau ungkapan. Hal itu dapat menentukan sopan-tidaknya ujaran yang diucapkan seseorang. Untuk itulah, para pengajar wajib mengetahui langkah-langkah saat mengajar agar tidak ada materi yang tertinggal atau lupa diajarkan. Untuk itulah, Alfiana menekankan agar para instruktur membuat Rencana Pengajaran. Banyak instruktur yang menganggap hal ini sebagai hal sepele karena mereka berpikir bahwa mengajar di tempat kursus atau LPK tidak memerlukan rencana yang detail. Namun, justru di situlah letak kekosongan yang wajib diisi dan dilakukan oleh setiap instruktur.

c) Materi tentang pentingnya pengetahuan latar belakang/budaya Korea yang disampaikan oleh Hwang Who Young sonsaengnim.

Hwang sonsaengnim menekankan pentingnya setiap pengajar untuk fokus pada topik dan target yang ada pada setiap bab di modul. Pengajar harus menguasai materi sebelum memulai mengajar dan harus belajar lebih rajin serta jujur agar terhindar dari pemberian informasi atau pengetahuan yang salah tentang bahasa dan budaya Korea. Untuk itulah, dia memulai pemaparan materi dengan menanyakan sebuah pertanyaan yang sederhana tentang bagaimana orang Korea menyerahkan atau memberikan barang kepada orang lain yang berusia lebih tua. Di situ terlihat sejauh mana pemahaman pengajar Indonesia terhadap budaya Korea. Hwang sonsaengnim memastikan agar para pengajar membaca modul dengan baik karena di dalam modul telah disampaikan terkait dengan ajaran-ajaran tata krama Korea. Untuk itulah, para pemateri wajib menggunakan buku sebagai materi yang dapat membantu pembelajaran bahasa Korea secara komprehensif, bukan hanya menganggapnya sebagai materi yang dianggap sepele sehingga dapat dilewatkan begitu saja.

d) Materi tata bahasa yang mudah dipahami, yang dibawakan oleh Iva Hanani. Secara singkat, Hana sonsaengnim meminta para pengajar untuk memastikan agar materi tata bahasa dapat disampaikan dengan mudah dan menarik.

Selama pemaparan, Hana sonsaengnim memastikan agar kelas tata bahasa dilaksanakan dengan menarik, tetapi semenantang mungkin, dengan cara, misalnya, para pengajar mengajak para peserta didiknya di LPK untuk belajar berbagai macam tata bahasa yang mirip. Bahasa Korea memiliki banyak tata bahasa yang memiliki kemiripan satu dengan lainnya, tetapi memiliki cara penggunaan yang berbeda. Untuk itulah, pengajar ditantang untuk dapat memberikan kelas tata bahasa yang menarik agar para peserta tidak patah semangat saat mempelajarinya. 


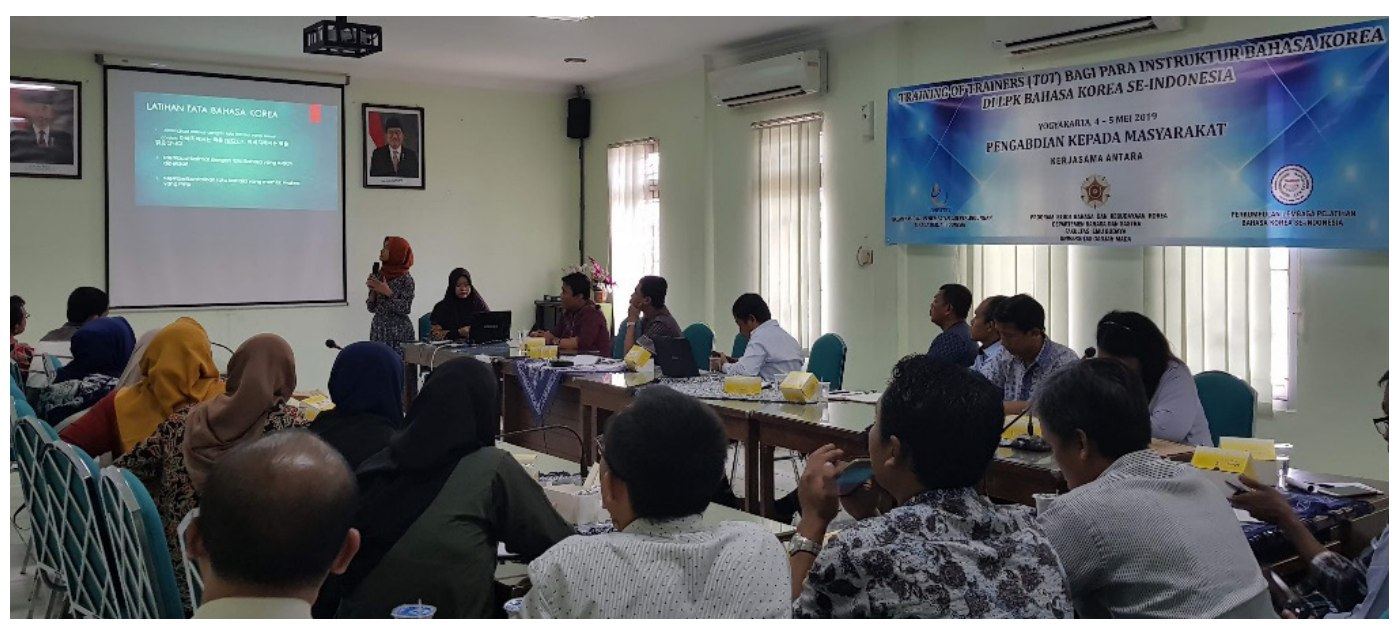

Gambar 4. Iva Hanani Sonsaengnim sedang Memaparkan Materi.

Secara singkat dapat dikatakan bahwa semua pengajar di Prodi Korea terlibat aktif dalam kegiatan ini, termasuk para mahasiswa yang membantu kelancaran PkM. Setiap pengajar Prodi Korea memiliki tugas untuk memberikan materi masing-masing sesuai dengan kemampuan dan kapasitas mereka.

\section{Catatan-Catatan Penting dari Para Peserta ToT}

Untuk menilai keberhasilan kegiatan $\mathrm{PkM}$ bagi para instruktur bahasa Korea, dalam bagian ini dipaparkan tanggapan dan permintaan para peserta PkM. Tanggapan mereka dibagi berdasarkan tiga hal, yaitu konten, metode ToT, dan harapan.

\section{Konten}

Para peserta menilai konten yang disampaikan sangat penting dan sesuai dengan yang mereka perlukan sebagai pengajar bahasa Korea di LPK. Namun, khusus untuk konten terkait dengan tata bahasa, para peserta menganggap bahwa waktunya sangat kurang walaupun telah ada dalam materi ToT.

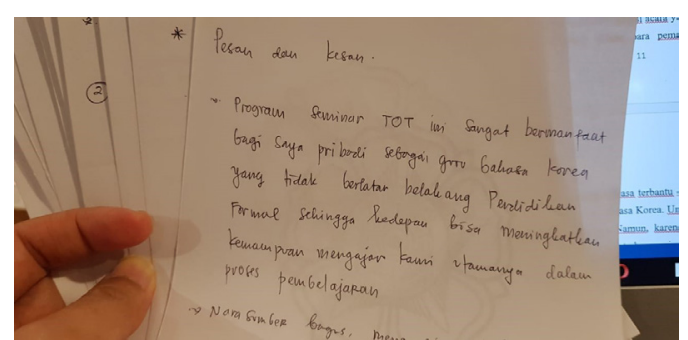

Gambar 5. Salah Satu Pesan dan Kesan Peserta terhadap Konten ToT.

\section{Metode ToT}

Rata-rata peserta mengapresiasi para pengisi acara yang menyampaikan konten dengan baik dan mudah dipahami. Ditambah dengan para pemateri yang ramah dan luwes dalam menyampaikan materi, mereka merasa terbantu dan sadar betapa kurangnya pemahaman mereka terhadap beberapa hal terkait dengan bahasa Korea. Untuk itu, mereka sangat senang karena ada materi terkait metodologi pengajaran. Namun, karena singkatnya waktu, sesi metode pengajaran belum dapat mencakup setiap metode pengajaran seperti kosakata, menyimak, berbicara, menulis, dan membaca secara menyeluruh. Oleh karena itu, selama ToT, para pemateri terlihat menaruh perhatian lebih hanya pada tata bahasa. 
Terlepas dari itu semua, para pemateri memberikan kesempatan kepada para peserta untuk saling berbagi pengalaman saat mengajarkan suatu tata bahasa. Para peserta sangat menyukai kegiatan semacam ini karena mereka dapat melihat dan saling belajar dari peserta lain atau dari pengajar LPK-LPK lain.

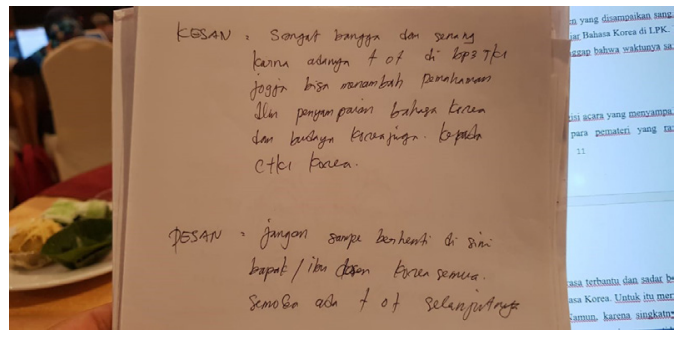

Gambar 6. Salah Satu Komentar Peserta terhadap Metode ToT.

\section{Harapan ke Depan}

Satu hal yang paling banyak ditulis dan diungkapkan oleh peserta adalah keinginan mereka untuk diadakannya kegiatan semacam ToT ini secara berkesinambungan. Mereka berharap kegiatan seperti ini tidak dilakukan di Yogyakarta saja, tetapi juga dibuat berseri dengan berpindah-pindah lokasi ke beberapa kota di Indonesia.

Pada dasarnya, para peserta memandang ToT melalui skema Pengabdian kepada Masyarakat seperti ini sangat membantu mereka karena mereka rata-rata belajar secara autodidak dan bukan merupakan pengajar bahasa Korea yang dibekali dengan pendidikan formal bahasa Korea. Untuk itulah, mereka berharap ToT tidak hanya dilaksanakan selama dua hari, tetapi perlu disambung dengan cara lain atau secara rutin agar mereka selalu mendapat bimbingan. Harapan lainnya adalah adanya program khusus selama 3 atau 6 bulan bagi para instruktur bahasa Korea. Program ini dapat diadakan di UGM dan mereka sanggup menganggarkan biaya jika nantinya diselenggarakan kegiatan semacam ini.

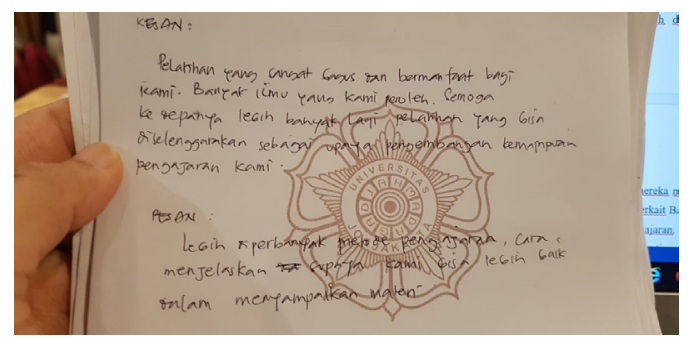

Gambar 7. Salah Satu Komentar Harapan Peserta.

\section{Kesimpulan}

Pengabdian kepada Masyarakat $(\mathrm{PkM})$ Program Studi Bahasa dan Kebudayaan Korea tahap ke-2 ini telah selesai dengan lancar. Training of Trainers (ToT) kepada para instruktur bahasa Korea ini diharapkan menumbuhkan rasa percaya diri para instruktur bahasa Korea di LPK-LPK Bahasa Korea di seluruh Indonesia. Seperti yang telah diketahui, kebanyakan para instruktur berasal dari mantan PMI yang tidak pernah mendapatkan pendidikan bahasa Korea secara formal. Oleh karena itu, sebuah program penyegaran bahasa Korea seperti ToT ini merupakah salah satu metode bagi para instruktur agar mereka mendapatkan pengalaman belajar bahasa Korea secara langsung, terutama terkait dengan bagaimana mengajarkan bahasa Korea dengan lebih baik lagi.

Oleh karena itu, sebagai penghargaan atas keinginan mereka untuk terus belajar dan atas kerja sama mereka untuk melancarkan kegiatan $\mathrm{PkM}$ ini, pihak Prodi memberikan sertifikat kepada setiap peserta ToT. Sertifikat ini menjadi bukti jembatan kini dan masa mendatang dalam hubungan antara Prodi Bahasa Korea dan masyarakat, terutama LPK-LPK Bahasa Korea se-Indonesia. 


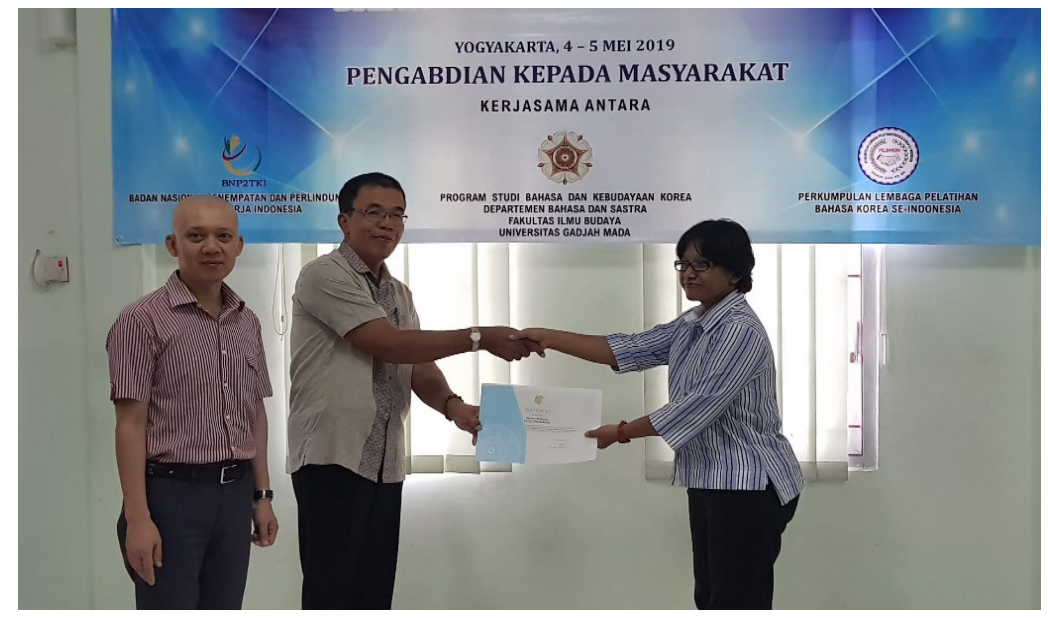

Gambar 8. Pemberian Sertifikat kepada Peserta PkM 2019.

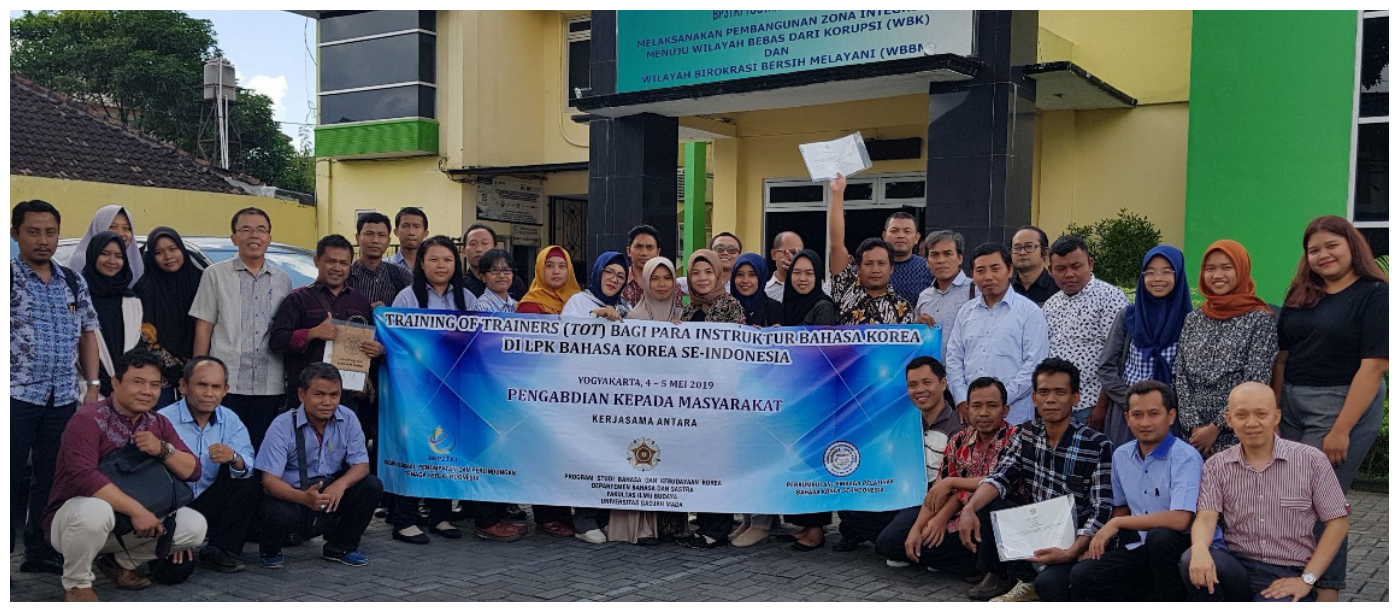

Gambar 9. Foto Bersama Seluruh Peserta dan Panitia PkM 2019.

\section{Daftar Pustaka}

Nugroho, Suray Agung. (2019). "Pendampingan EPS TOPIK (Employment Permit System Test of Proficiency in Korean Language) bagi Calon Pekerja Migran Indonesia dari Provinsi D.I. Yogyakarta” dalam Bakti Budaya, Vol. 2, No. 1, April 2019, hlm. 74-82. 